\title{
A Study of Stress Complications among Employees during Covid-19 Pandemic Special References to Chennai City
}

\section{OPEN ACCESS}

Manuscript ID:

MGT-2021-08033371

Volume: 8

Issue: 3

Month: January

Year: 2021

P-ISSN: 2321-4643

E-ISSN: 2581-9402

Received: 24.10 .2020

Accepted: 30.11 .2020

Published: 01.01.2021

\section{Citation:}

Vijai, C., and P. Nivetha. "A Study of Stress Complications among Employees during Covid-19 Pandemic Special References to Chennai City." Shanlax International Journal of Management, vol. 8, no. 3, 2021, pp. 37-45.

DOI:

https://doi.org/10.34293/ management.v8i3.3371

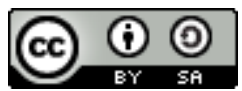

This work is licensed under a Creative Commons Attribution-ShareAlike 4.0 International License.

\section{Vijai}

Assistant Professor, Department of Commerce

St. Peter's Institute of Higher Education and Research, Chennai, Tamil Nadu, India

D https://orcid.org/0000-0003-0041-7466

\section{P. Nivetha}

Research Scholar, Department of Commerce,

St. Peter's Institute of Higher Education and Research, Chennai, Tamil Nadu, India

\section{Abstract}

Nowadays, stress is a common word used in day-to-day life. With the spread of the coronavirus, many states have issued stay-at-home orders. Many companies have mandated that employees work from home to help stop the spread of COVID-19 between members of your staff with other employees and their families. This research finds out employee work from home stress complicates during Covid-19 Lockdown. The primary data were collected through structured questionnaires from 454 respondents using Google form. The majority was $45 \%$ of the respondents are male, $43 \%$ of the respondents are 21-30 years age group, 40\% of the respondents are Diploma/ITI qualified, $35 \%$ of the respondents are Rs. 20,001 to Rs. 30,000 income group,\% of the respondents are not feeling stressing in accepting all works, $47 \%$ of the respondents are not accepted lockdown increase work pressure, majority of the respondents are not doing work from home and it is found that the majority of respondents employed in the private sector and the majority of respondents do not accept normal working days better than this lockdown. Data were processed and analyzed by the Statistical Package for social science. A chi-square test was used to investigate the level of association among variables at the significance level of $p<0.05$. This study to find out the stress complication among employees during COVID -19 special references to Chennai City.

Keywords: Stress, COVID-19, Work from home, Employee perception, Work-life balance, Workplace stress

\section{Introduction}

Stress is directly related to the nature of work. It is necessary to focus on and reduce during the COVID-19 Pandemic situation. Many companies have mandated that employees work from home to help stop the spread of COVID-19 between members of your staff with other employees and their families.

The organization to recognize current employee situations by information Gathering, data should include staff understanding of their working conditions, stress level, health and satisfaction and atmosphere of the workplace.

Employees have given priority to work and family in balance. Management should motivate the employees to push them to do better and keep trying in all crises. Stress is controllable; employees have to concentrate on the balance between good stress and bad stress. Employees need to stay motivated and productive; it reduces Stress. In this curious condition, employees are focused and efficient during this work-from-home, Maintaining work-life balance, take sufficient breaks, follow a schedule, keep do listing, eliminating distraction. 


\section{Literature Review}

The Potential Impact of the Covid-19 Pandemic on Occupational Status, Work from Home, and Occupational Mobility. The impact of the COVID-19 pandemic affects people's life and work, perception of the value and status of the occupation may change, occupational supply and demand change, micro and macro change. Many organizations adopt work from home culture during the present economic crisis and provide occupational segmentation changes. Some individuals, in some occupations, are better suited to work from home or not suitable. The current pandemic, affecting all occupational groups' impact on low-wage, lay off. Employees are very limited in their ability to work away from the physical location of their work, concentrated in occupations that suffer from high turnover and poor working conditions.

The Covid-19 pandemic leads to social distancing to reduce the spread of the virus. Many organizations closed regular operations, and most of the institutions provide work from home to the employees. Switching to work from home more familiar to highly educated, high income, and white workers, and much less among minorities, workers with lower incomes, and high school degrees. Information on actual workfrom-home behavior of workers, worked from home before the virus outbreak shows a little relationship with employment outcomes. Home-based workers in hard-hit industries became unemployed suggest labor-demand also plays matters for employment losses. Work from Home during COVID-19: Employees Perception and Experiences. The Corona virus (COVID-19) pandemic, number of employees adopting remote work globally. In the present economic crisis, most organizations adopt flexible work arrangements for employees working from home. The outcomes of these arrangements consist of both positive and negative. In this study, employees' willingness to work from home stressful due to the presence of their children at home, uncomfortable space at home, lack of quiet environment at home and poor internet connectivity.

\section{Meaning of Stress}

Stress is defined as a state of mental and emotional pressure or strain caused by challenging or unfavorable circumstances.
Stress represents a situation where a person is under pressure and does not have sufficient ability to cope. Stress also indicates a direct negative reaction both for individuals and organizations by undermining the original goals attainment.

Physical and physiological effects on a person can be a mental, physical, or emotional strain. Nervous tension arises from internal conflicts because of external situations

\section{Employee Work Stress on COVID-19 Pandemic}

The COVID-19 pandemic has affected both personal life and work life. Individuals facing difficulties like Concern about the risk of being exposed to the virus at work, Taking care of personal and family needs while working, uncertainty about the future, etc. The Mental Health Foundation had found that nearly three-quarters of people had feeling stress, and before the pandemic. Stress leads to mental health problems, depression, etc.

Identify stressors and employee's mental health during or post COVID-19 outbreak. Stressors during the corona virus pandemic. Are quarantine and social distancing, finanacial loss and job insecurity, lack of social support, perception of safety, threat and risk of transmission. Work stress can be caused by poor work culture, poor work design, poor management, unsatisfactory working conditions, lack of support from colleagues and supervisors, work load, work pace, working hours, half salary, uncertain termination, career development and work-life balance.

According to the citizen engagement platform, Local Circles conducted an online survey; there has been a 166 percent increase in Indians complaining of anxiety from lockdown 1.0 to unlock 1.0. The percentage of adults aged 18-29 year's psychological stress increased from 3.7 percent in 2018 to 24 percent in 2020. Individuals' annual household income of less than $\$ 35,000$ showed increased mental stress by 11.4 percentage points. Psychological distress increased from 3.9 percent in 2018 to 13.6 percent in April 2020.

Organizations have to reduce employee work stress during the present crisis. Employer provides recognition to employee work status, providing transparent communication about organization 
SHANLAX

International Journal of Management sysm

operations, frame employee supportive policy and procedures, prepare supervisors ready to help employee, provide information and educate employee during this pandemic.

\section{Method of Research}

Objective: The present study's core objective is to determine the Stress complications among employees during the Covid-19 pandemic. Special Reference with Chennai City. A survey was conducted from 1st March 2020 to May 31st, 2020.

Research Design: The sample size of the research is 454 respondents. The research area has been the employees in work from home during the COVID-19 pandemic who have experienced or are experiencing work-related stress in their situation. Collection of primary data through using Google forms questionnaire responses are consisting of responsive questions. Collection of secondary data through Journals, published papers, articles, handbooks was referred to gain further insight into the topic. The Statistical Package for social science tools used in the research is percentage analysis and chi-square test.

\section{Data Analysis and Interpretation}

Table 1: Socioeconomic and Demographic Variables among Respondents

\begin{tabular}{|c|l|c|c|}
\hline \multirow{4}{*}{ Variables } & \multicolumn{1}{|c|}{ Category } & $\begin{array}{c}\text { No. of } \\
\text { Respondents }\end{array}$ & \% \\
\hline \multirow{4}{*}{ Gender } & Male & 203 & 43 \\
\cline { 2 - 4 } & Female & 195 & 45 \\
\cline { 2 - 4 } & Prefer not to say & 56 & 12 \\
\cline { 2 - 4 } & \multicolumn{1}{|c|}{ Total } & 454 & 100 \\
\hline \multirow{5}{*}{ Age } & $21-30$ & 197 & 43 \\
\cline { 2 - 4 } & $31-40$ & 119 & 26 \\
\cline { 2 - 4 } & Above 40 & 27 & 6 \\
\cline { 2 - 4 } & Upto 20 & 111 & 25 \\
\cline { 2 - 4 } & & 454 & 100 \\
\hline \multirow{5}{*}{ Letal } & Diploma/ITI & 181 & 40 \\
\cline { 2 - 4 } & UG & 120 & 26 \\
\cline { 2 - 4 } & P.G and above & 38 & 8 \\
\cline { 2 - 4 } & Upto H.Sc & 115 & 25 \\
\cline { 2 - 4 } & & 454 & 100 \\
\hline
\end{tabular}

\begin{tabular}{|c|c|c|c|}
\hline \multirow{5}{*}{ Occupation } & Private sector & 208 & 46 \\
\hline & Public sector & 120 & 26 \\
\hline & Business & 105 & 23 \\
\hline & Agriculture & 21 & 5 \\
\hline & Total & 454 & 100 \\
\hline \multirow{5}{*}{$\begin{array}{l}\text { Monthly } \\
\text { income } \\
\text { (Rs) }\end{array}$} & Upto Rs.20,000 & 134 & 30 \\
\hline & $\begin{array}{l}\text { Rs. } 20,001 \text { - } \\
\text { Rs. } 30,000\end{array}$ & 157 & 35 \\
\hline & $\begin{array}{l}\text { Rs. } 30,001 \text { - } \\
\text { Rs. } 40,000\end{array}$ & 127 & 28 \\
\hline & Above Rs. 40,000 & 36 & 8 \\
\hline & Total & 454 & 100 \\
\hline
\end{tabular}

Source: Computed from Primary Data

\section{Interpretation}

Table 1 shows $45 \%$ of the respondents are female, $43 \%$ of the respondents are male and $12 \%$ of the respondents are gender not prefer. The majority of the respondents are female gender. $43 \%$ of the respondents are 21-30 age groups, $26 \%$ of the respondents are $31-40$ age group, $25 \%$ of the respondents up to 20 age group and $6 \%$ of the respondents are above 50 age group. $40 \%$ of the respondents are diploma/ITI qualified, 26\% of the respondents are under graduated, $25 \%$ of the respondents are qualified up to H.Sc and $8 \%$ are $\mathrm{PG}$ and above qualified. The majority of the respondents are Diploma/ITI qualified. The $35 \%$ of the respondents are Rs.20,001-Rs.30,000 income group, $30 \%$ of the respondents are Up to Rs.20,000 income group, $28 \%$ of the respondents are Rs.30,001-Rs.40,000 income group and $8 \%$ of the respondents are Rs. 40,000 income group. $46 \%$ of the respondents are employed in the private sector, $26 \%$ of the respondents are employed public sector, 23\% of the respondents are doing business and $5 \%$ of the respondents are agriculturists. The majority of the respondents are employed in the private sector.

Table 2: Respondents doing Work from Home

\begin{tabular}{|c|c|c|}
\hline Variables & Frequency & Percentage \\
\hline Yes & 171 & 38 \\
\hline No & 197 & 43 \\
\hline Maybe & 86 & 19 \\
\hline Total & 454 & 100 \\
\hline
\end{tabular}

Source: Computed from Primary Data 


\section{Interpretation}

Table 2 shows, $43 \%$ of the respondents, are not doing work from home, $38 \%$ of the respondents are doing work from home and $19 \%$ of the respondents may be doing work from home. The majority of the respondents are not doing work from home.

Table 3: Management Provide a Work Schedule

\begin{tabular}{|l|c|c|}
\hline Variables & Frequency & Percentage \\
\hline Yes & 155 & 34 \\
\hline No & 209 & 46 \\
\hline Maybe & 90 & 20 \\
\hline Total & 454 & 100 \\
\hline
\end{tabular}

Source: Computed from Primary Data

\section{Interpretation}

Table 3 shows, $46 \%$ of respondent's management does not provide a work schedule, $34 \%$ of the respondent's management provides a work schedule and $20 \%$ of the respondent's management may provide a work schedule. Majority of the respondents' management does not provide a work schedule.

Table 4: Feel Spend Much Time in Work during a Lockdown

\begin{tabular}{|l|c|c|}
\hline Variables & Frequency & Percentage \\
\hline Yes & 161 & 35 \\
\hline No & 208 & 46 \\
\hline Maybe & 85 & 19 \\
\hline Total & 454 & 100 \\
\hline
\end{tabular}

Source: Computed from Primary Data

\section{Interpretation}

Table 4 shows, $46 \%$ of the respondents are not feel they spend much time in work during a lockdown, $35 \%$ of the respondents are feeling they spend much time in work during a lockdown and $19 \%$ of the respondents may feel they spend much time in work during the lockdown. The majority of the respondents are not feeling to spend much time at work during the lockdown.

Table 5: Feel Stressing in Accepting All Works

\begin{tabular}{|l|c|c|}
\hline \multicolumn{1}{|c|}{ Variables } & Frequency & Percentage \\
\hline Yes & 174 & 38 \\
\hline No & 202 & 44 \\
\hline Maybe & 78 & 17 \\
\hline Total & 454 & 100 \\
\hline
\end{tabular}

Source: Computed from Primary Data

\section{Interpretation}

Table 5 shows, $44 \%$ of the respondents, are not feel stressing in accepting all works, $38 \%$ of the respondents are feeling stressing in accepting all works and $17 \%$ of respondents are may feel stressing in accepting all works. Majority of respondents are not feeling stressing in accepting all works.

Table 6: Are you agree Lockdown Increased Work Pressure

\begin{tabular}{|c|c|c|}
\hline Variables & Frequency & Percentage \\
\hline Yes & 158 & 35 \\
\hline No & 215 & 47 \\
\hline Maybe & 81 & 18 \\
\hline Total & 454 & 100 \\
\hline
\end{tabular}

\section{Interpretation}

Table 6 shows, $47 \%$ of the respondents are not accepted lockdown increase work pressure, 35\% of the respondents are accepted lockdown increase work pressure, and $18 \%$ of the respondents may be accepted lockdown increase work pressure Majority of the respondents are not accepting lockdown increase work pressure.

Table 7: Management Forced to Attend an Online Meeting

\begin{tabular}{|l|c|c|}
\hline Variables & Frequency & Percentage \\
\hline Yes & 131 & 29 \\
\hline No & 236 & 52 \\
\hline Maybe & 87 & 19 \\
\hline Total & 454 & 100 \\
\hline
\end{tabular}

Source: Computed from Primary Data

\section{Interpretation}

Table 7 shows, $52 \%$ of the respondents are not management forced to attend an online meeting, $29 \%$ of the respondents are management forced to attend an online meeting and $19 \%$ of the respondents are may be management forced to attend an online meeting. The majority of the respondents are not management forced to attend an online meeting.

Table 8: Attend the Online Meeting in a Week

\begin{tabular}{|l|c|c|}
\hline \multicolumn{1}{|c|}{ Variables } & Frequency & Percentage \\
\hline 1 hour & 101 & 22 \\
\hline 2 hours & 106 & 23 \\
\hline
\end{tabular}




\begin{tabular}{|c|c|c|}
\hline 3 hours & 101 & 22 \\
\hline More than 3 hours & 64 & 14 \\
\hline Nil & 82 & 18 \\
\hline Total & 454 & 100 \\
\hline
\end{tabular}

Source: Computed from Primary Data

\section{Interpretation}

Table 8 shows, $23 \%$ of the respondents are spending 2 hours to attend an online meeting in a week, $22 \%$ of the respondents are spending 1hour and 3 hours to attend an online meeting in a week, $18 \%$ of the respondents are not attending an online meeting in a week and $14 \%$ of the respondents are spending more than 3 hours to attend an online meeting in a week. The majority of the respondents are spending 2 hours to attend an online meeting in a week.

Table 9: Management Provides any Appreciation

\begin{tabular}{|l|c|c|}
\hline Variables & Frequency & Percentage \\
\hline Yes & 162 & 36 \\
\hline No & 215 & 47 \\
\hline Maybe & 77 & 17 \\
\hline \multicolumn{1}{|c|}{ Total } & 454 & 100 \\
\hline
\end{tabular}

Source: Computed from Primary Data

\section{Interpretation}

Table 9 shows, $47 \%$ of the respondents are not management provide any appreciation, 36\% of the respondents are management provide any appreciation and $17 \%$ of the respondents are may be management provide any appreciation. The majority of the respondents are not management provide any appreciation

Table 10: Healthy Relationship with your Colleagues Variables

\begin{tabular}{|l|c|c|}
\hline \multicolumn{1}{|c|}{ Variables } & Frequency & Percentage \\
\hline Yes & 148 & 33 \\
\hline No & 202 & 44 \\
\hline Maybe & 104 & 23 \\
\hline Total & 454 & 100 \\
\hline
\end{tabular}

Source: Computed from Primary Data

\section{Interpretation}

Table 10 shows, $44 \%$ of the respondents are not feeling a healthy relationship with their colleagues, $33 \%$ of the respondents are feeling a healthy relationship with their colleagues and $23 \%$ of the respondents are may feel a healthy relationship with their colleagues. The majority of the respondents are not feeling healthy relationships with their colleagues.

Table 11: Accept if the Management is Reducing your Salary to some Extent

\begin{tabular}{|l|c|c|}
\hline Variables & Frequency & Percentage \\
\hline Yes & 163 & 36 \\
\hline No & 199 & 44 \\
\hline Maybe & 92 & 20 \\
\hline Total & 454 & 100 \\
\hline
\end{tabular}

Source: Computed from Primary Data

\section{Interpretation}

Table 11 shows, 44\% of the respondents are not accepted if the management is reducing your salary to some extent, $36 \%$ of the respondents are accepted if the management is reducing your salary to some extent and $20 \%$ of the respondents may be accepted if the management is reducing your salary to some extent. The majority of the respondents are not acceptable if the management is reducing your salary to some extent.

Table 12: Spend Time Along with Family Members during a Lockdown

\begin{tabular}{|l|c|c|}
\hline Variables & Frequency & Percentage \\
\hline Yes & 153 & 34 \\
\hline No & 207 & 46 \\
\hline Maybe & 94 & 20 \\
\hline Total & 454 & 100 \\
\hline
\end{tabular}

Source: Computed from Primary Data

\section{Interpretation}

Table 12 shows, $46 \%$ of the respondents are not spend time along with family members during a lockdown, $34 \%$ of the respondents are spending time along with family members during a lockdown and $20 \%$ of the respondents are may be spending time along with family members during a lockdown. The majority of the respondents are not spending time along with family members during a lockdown. 
International Journal of Management

Table 13: Management Considers Employee Responsibilities in a Family

\begin{tabular}{|l|c|c|}
\hline Variables & Frequency & Percentage \\
\hline Yes & 153 & 34 \\
\hline No & 222 & 49 \\
\hline Maybe & 79 & 17 \\
\hline Total & 454 & 100 \\
\hline
\end{tabular}

Source: Computed from Primary Data

\section{Interpretation}

Table 13 shows, $49 \%$ of respondent's management did not consider employee responsibilities in the family, $34 \%$ of the respondent's management consider employee responsibilities in the family and $17 \%$ of the respondent's management may consider employee responsibilities in the family. The majority of the respondents' management did not consider employee responsibilities in the family.
Table 14: Accept Normal Working Days Better than this Lockdown

\begin{tabular}{|l|c|c|}
\hline Variables & Frequency & Percentage \\
\hline Yes & 198 & 44 \\
\hline No & 209 & 46 \\
\hline Maybe & 47 & 10 \\
\hline Total & 454 & 100 \\
\hline
\end{tabular}

Source: Computed from Primary Data

\section{Interpretation}

Table 14 shows, $46 \%$ of the respondents are not accepted normal working days better than this lockdown, $44 \%$ of the respondents are accepted normal working days better than this lockdown and $10 \%$ of the respondents may accept normal working days better than this lockdown. The majority of the respondents are not accepted normal working days better than this lockdown.

Table 15: Hypothesis Testing

\begin{tabular}{|c|l|l|c|c|}
\hline $\begin{array}{c}\text { S. } \\
\text { No }\end{array}$ & \multicolumn{1}{|c|}{ Null Hypothesis } & \multicolumn{1}{|c|}{$\begin{array}{c}\text { Test } \\
\text { Statistics }\end{array}$} & $\begin{array}{c}\text { Calculated } \\
\text { Value }\end{array}$ & $\begin{array}{c}\text { Accepted } / \\
\text { Rejected }\end{array}$ \\
\hline 1 & Gender is not associated work from home & Chi-Square & 0.002 & Rejected \\
\hline 2 & Gender is not associated with management provide work schedule & Chi-Square & 0.001 & Rejected \\
\hline 3 & Gender is not associated spend much time in work during lockdown & Chi-Square & 0.002 & Rejected \\
\hline 4 & Gender is not associated feeling stressing in accepting all works & Chi-Square & 0.003 & Rejected \\
\hline 5 & Gender is not associated accept lockdown increase work pressure & Chi-Square & 0.000 & Rejected \\
\hline 6 & $\begin{array}{l}\text { Gender is not associated management forced to attend online } \\
\text { meeting }\end{array}$ & Chi-Square & 0.015 & Rejected \\
\hline 7 & $\begin{array}{l}\text { Gender is not associated how many hours attend online meeting in } \\
\text { a week }\end{array}$ & Chi-Square & 0.000 & Rejected \\
\hline 8 & Gender is not associated management provide any appreciation & Chi-Square & 0.000 & Rejected \\
\hline 9 & $\begin{array}{l}\text { Gender is not associated feel healthy relationship with your } \\
\text { colleagues }\end{array}$ & Chi-Square & 0.000 & Rejected \\
\hline 10 & $\begin{array}{l}\text { Gender is not associated accept if the management is reducing } \\
\text { salary to some extent }\end{array}$ & Chi-Square & 0.002 & Rejected \\
\hline 11 & $\begin{array}{l}\text { Gender is not associated spend time along with family member } \\
\text { during lockdown }\end{array}$ & Chi-Square & 0.000 & Rejected \\
\hline 12 & $\begin{array}{l}\text { Gender is not associated management consider employee } \\
\text { responsibilities in family }\end{array}$ & Chi-Square & 0.000 & Rejected \\
\hline 13 & $\begin{array}{l}\text { Gender is not associated accept normal working days better than } \\
\text { this lockdown holidays }\end{array}$ & Chi-Square & 0.316 & Accepted \\
\hline 14 & Employment is not associated work from home & Chi-Square & 0.000 & Rejected \\
\hline 15 & $\begin{array}{l}\text { Employment is not associated spend much time in work during } \\
\text { lockdown }\end{array}$ & Chi-Square & 0.001 & Rejected \\
\hline
\end{tabular}


SHANLAX

International Journal of Management sump

\begin{tabular}{|c|l|l|c|c|}
\hline 16 & $\begin{array}{l}\text { Employment is not associated feeling stressing in accepting all } \\
\text { works }\end{array}$ & Chi-Square & 0.001 & Rejected \\
\hline 17 & $\begin{array}{l}\text { Employment is not associated management forced to attend online } \\
\text { meeting }\end{array}$ & Chi-Square & 0.001 & Rejected \\
\hline 18 & $\begin{array}{l}\text { Employment is not associated how many hours attend online } \\
\text { meeting in a week }\end{array}$ & Chi-Square & 0.002 & Rejected \\
\hline 19 & $\begin{array}{l}\text { Employment is not associated management provide any } \\
\text { appreciation }\end{array}$ & Chi-Square & 0.003 & Rejected \\
\hline 20 & $\begin{array}{l}\text { Employment is not associated feel healthy relationship with your } \\
\text { colleagues }\end{array}$ & Chi-Square & 0.002 & Rejected \\
\hline 21 & $\begin{array}{l}\text { Employment is not associated accept if the management is reducing } \\
\text { salary to some extent }\end{array}$ & Chi-Square & 0.000 & Rejected \\
\hline 22 & $\begin{array}{l}\text { Employment is not associated spend time along with family member } \\
\text { during lockdown }\end{array}$ & Chi-Square & 0.240 & Accepted \\
\hline 23 & $\begin{array}{l}\text { Employment is not associated management consider employee } \\
\text { responsibilities in family }\end{array}$ & Chi-Square & 0.002 & Rejected \\
\hline 24 & $\begin{array}{l}\text { Employment is not associated accept normal working days better } \\
\text { than this lockdown holidays }\end{array}$ & Chi-Square & 0.632 & Accepted \\
\hline 25 & $\begin{array}{l}\text { Income is not associated accept if the management is reducing } \\
\text { salary to some extent }\end{array}$ & Chi-Square & 0.001 & Rejected \\
\hline 26 & Age is not associated feeling stressing in accepting all works & Chi-Square & 0.001 & Rejected \\
\hline
\end{tabular}

Source: Computed from Primary Data

\section{Results and Discussion}

Gender high level of significant association with work from home, the calculated P-value is 0.002. Highly significant associated gender with management provides work schedule; the calculated $\mathrm{P}$-value is 0.001 . Gender high significant associated gender with spending much time in work during a lockdown, the calculated P-value is 0.002 . Highly significant associated gender with feeling stressing in accepting all works, the calculated P-value is 0.003 . Gender high level of associated with accept lockdown increase work pressure, calculated value 0.000 . Highly significant associated gender with management forced to attend an online meeting, calculated P-value 0.015. Gender high level associated with how many hours attend an online meeting in a week, the calculated P-value is 0.000 . Highly significant associated gender with management provides appreciation; the calculated value is 0.000 . Gender high level of associated with acceptance if the management is reducing salary to some extent, the calculated P-value is 0.002 . Since the P-value is less than $0.05 \%$. Hence, all the above null hypothesis is rejected.
Gender has a high level of significant association with spend time along with family members during a lockdown; the calculated P-value is 0.000 . Highly significant associated gender with management considers employee responsibilities in the family, calculated P-value 0.000. Since P-value is less than $0.05 \%$, hence, all the above null hypothesis is rejected. Gender has low significant associated gender with accepting normal working days better than this lockdown holidays; the calculated P-value is 0.316 . Since the P-value is greater than 0.05 . Hence the null hypothesis is accepted.

Educations have a high level of significant association with work from home; the calculated P-value is 0.000 . Educations have a high level of significant association with spending much time in work during a lockdown; the calculated P-value is 0.001. Educations have a high level of significant association with stressing in accepting all works; calculated P-value is 0.001 . Educations have a high level of significant association with management forced to attend online meetings; calculated P-value is 0.001. Educations have a high level of significant association with stressing in accepting all works; the 
estimated P-value is 0.001 . Educations have a high level of significant association with management forced to attend an online meeting; the calculated $\mathrm{P}$-value is 0.001. Educations have a high level of significant association with feeling a healthy relationship with your colleagues; the calculated chisquare $\mathrm{P}$-value is 0.002 . Since the above $\mathrm{P}$ values are less than 0.05 . Hence, the null hypothesis is rejected.

Educations have a high level of significant association with management is reducing salary to some extent, Calculated P-value is 0.000 . Educations have a lower level of significant association with spend time along with family members during lockdown; Calculated P-value is 0.240. Since the P-value is greater than 0.05 . Hence, the null hypothesis is accepted. Educations have a high level of significant association with management consider employee responsibilities in the family; calculated chi-square P-value is 0.002 Since P-value is less than 0.05 . Hence, the null hypothesis is rejected.

Educations have a lower level of significant association with accepting normal working days better than these lockdown holidays; the calculated $\mathrm{P}$-value is 0.632 Since P-value is greater than 0.05 . Hence, the null hypothesis is accepted. Incomes have a high level of significant association with acceptance if the management reduces salary to some extent; the calculated P-value is 0.001 . Ages have a high level of significant association with feeling stressing in accepting all works. The calculated chi-square $\mathrm{P}$-value is 0.001 . Since the P-value is less than 0.05 . Hence, the null hypothesis is rejected.

\section{Suggestions}

The coronavirus pandemic is causing stress for everyone. But it may be even more stressful for employees with disabilities. The prominence of stress among the workforce could prove costly for employers, especially nonessential businesses, seeking to optimize workflow amid the pandemic (Matthew Gavidia (2020)

During times of uncertainty and high stress, it's helpful to remember that you're not alone in how you feel. Leaders play a key role in helping to guide and support their employees in a kind and compassionate way. Everyone will deal with this situation differently, so in the context of recent events, organizations should enable and empower employees to make decisions around their health that best suit them, whether that is work-from-home options and flexible schedules outside of normal hours.

\section{Conclusion}

It was concerned by pressure from the environment. It defines the interaction between the individual and the situation. During COVID -19 Pandemic crises, many concerns provided work at home to employees. Environmental crises organizations concentrate on employee work conditions, difficulties and problems. Companies consider employees' stress factors like lack of resources, long hours of work, overload, poor management support, domestic pressure, etc., and employees equally concentrate on both office and home work.

Individuals to identify sources of stress, and then follow 4A's Avoid, alter, adapt and accept, spending quality time to family members and friends, balance a healthy lifestyle, follow quick stress relieve aspect. The organization has to recognize current employee situations by information Gathering; data should include staff understanding of their working conditions, stress level, health and satisfaction, analyzing the situation and developing an action plan to minimize the stressors, practicing self-confidence and motivation to continue.

\section{References}

Acevedo, Deepa Das. Searching for Silver Linings during COVID-19.

Anghel, Brindusa, et al. Transferability of Workers' Skills in Sectors Potentially Affected by Covid-19.

Baert, Stijn, et al. How Do We Think the Covid-19 Crisis Will Affect Our Careers (If Any Remain)?, IZA DP No. 13164, 2020.

Bick, Alexander, et al. Work from Home after the Covid-19 Outbreak, FRBD Working Paper No. 2017, 2020.

Brudney, James J. Forsaken Heroes: Covid-19 and Frontline Essential Workers, 2020.

Chandra, Jagriti. "Stress and Anxiety Rise amid Coronavirus Pandemic." The Hindu, 2020.

Chiuffo, Facundo Martin. "COVID-19 and Labour 
Law: Argentina." Italian Labour Law e-Journal, vol. 13, 2020.

Choudhari, Ranjana. COVID-19 Pandemic: Mental Health Challenges of Internal Migrant Workers of India.

Choudhury, Prithwiraj, et al. Working (From Home) During a Crisis: Online Social Contributions by Workers During the Coronavirus Shock, HBS Working Paper 20-096, 2020.

Das, Kishore Kumar, and Shalini Patnaik. "The Impact of COVID-19 in Indian Economy - An Empirical Study." International Journal of Electrical Engineering and Technology, vol. 11, no. 3, 2020, pp. 194-202.

Din, Nizam Ud, et al. COVID-19 Crisis Shifts the Career Paradigm of Women and Maligns the Labour Market: A Gender Lens.

Dutta, Prabhash K. "How Covid-19 Affected Anxiety Level among Indians between Lockdown 1.0 and Unlock 1.0." India Today, 2020.

"Employees: How to Cope with Job Stress and Build Resilience During the COVID-19 Pandemic." Centers for Disease Control and Prevention, 2020.

"Employee Stress Management through COVID-19." Top Employers Institute, 2020.

Estupinan, Xavier, et al. Impact of COVID-19 Pandemic on Labor Supply and Gross Value Added in India.

Gavidia, Matthew. "How has COVID-19 Affected Mental Health, Severity of Stress Among Employees?" AJMC, 2020.

Hamouche, Salima. "COVID-19 and Employees' Mental Health: Stressors, Moderators and Agenda for Organizational Actions." Emerald
Open Research, vol. 2, 2020.

Kramer, Amit, and Karen Z. Kramer. "The Potential Impact of the Covid-19 Pandemic on Occupational Status, Work from Home, and Occupational Mobility." Journal of Vocational Behavior, vol. 119, 2020.

Lord, Phil. Incentivising Employment during the COVID-19 Pandemic, https://papers.ssrn. $\mathrm{com} / \mathrm{sol} /$ papers.cfm?abstract_id $=3573176$

Nanda, Jyotsnamayee. Impact of Lockdown for COVID-19 on Female Domestic Workers: A Case Study from Cuttack City.

Rathore, Udayan, and Shantanu Khanna. From Slowdown to Lockdown: Effects of the COVID-19 Crisis on Small Firms in India.

Shan, Chenyu, and Dragon Yongjun Tang. The Value of Employee Satisfaction in Disastrous Times: Evidence from COVID-19.

Shareena, P., and Mahammad Shahid. "Work from Home during COVID-19: Employees Perception and Experiences." Global Journal for Research Analysis, vol. 9, no. 5, 2020.

Solanki, Shweta. An Exploratory Study on Behavioral Science of HR Mangers to Respond the COVID-19 Challenge.

Srinivasan, Vinithra. Employment Issues During COVID-19 Crisis: An Analysis of the MHA's Order.

Von Batten, Karl. The First 100 Days: The Effects of the COVID-19 Pandemic on Healthcare Workers' Efficacy and Absenteeism in the United States and the United Kingdom.

"What is Stress? Definition, Classification and Sources." Business Jargons, https:// businessjargons.com/stress.html

\section{Author Details}

Dr. C. Vijai, Assistant Professor, Department of Commerce, St. Peter's Institute of Higher Education and Research, Chennai, Tamil Nadu, India, Email ID: vijaialvar@gmail.com.

Ms. P. Nivetha, M. Phil. Research Scholar, Department of Commerce, St. Peter's Institute of Higher Education and Research, Chennai, Tamil Nadu, India. 